\title{
KNOWLEDGE MANAGEMENT SYSTEM DENGAN SECI MODEL SEBAGAI MEDIA KNOWLEDGE SHARING PADA PROSES PENGEMBANGAN PERANGKAT LUNAK DI PUSAT KOMPUTER UNIVERSITAS TARUMANAGARA
}

\author{
Rahmat Nurcahyo ${ }^{1}$, Dana Indra Sensuse ${ }^{2}$ \\ Program Studi Magister Ilmu Komputer, Fakultas Teknologi Informasi, Universitas Budi Luhur \\ Jl. Raya Ciledug, Petukangan Utara, Kebayoran Lama, Jakarta Selatan 12260 \\ Telp. (021) 5853753, Fax. (021) 5869225 \\ Email: rahmatnc29@gmail.com
}

\begin{abstract}
ABSTRAK
Pengembangan perangkat lunak di Universitas Tarumanagara (UNTAR) dilaksanakan oleh bagian Pusat Komputer yang merupakan unit dibawah Direktorat Sistem Informasi dan Database. Proses pengembangan perangkat lunak dilakukan oleh tim pengembangan yang terdiri atas beberapa orang programmer senior dan junior. Di dalam tim tersebut masing-masing programmer memiliki kompetensi, latar belakang programming, coding model, serta pengalaman yang berbeda. Perbedaan inilah yang kemudian menimbulkan kesenjangan dari sisi pengetahuan dan pemahaman terhadap pekerjaan yang dilakukan, hal ini tentu dapat menghambat aktifitas pekerjaan terkait pengembangan perangkat lunak. Di samping itu pengetahuan juga merupakan aset yang berharga bagi perusahaan atau organisasi yang harus di kelola, di simpan dan di sharing kepada orangorang di dalam perusahaan atau organisasi tersebut. Untuk itu tujuan penelitian ini adalah membuat sebuah Knowledge Management Sytem sebagai media knowledge sharing antar programmer guna mendukung pengelolaan pengetahuan dan berbagi pengetahuan diantara programmer-programmer di dalam tim pengembangan perangkat lunak. Penelitian ini menggunakan pendekatan SECI Model. Hasil penelitian menghasilkan sebuah rancangan Knowledge Management System dengan fitur-fitur berupa collaboration project, forum online, web portal KMS, blog, knowledge repository, document management system, dan study case. Pengujian menggunakan user acceptance test, dimana diperoleh hasil bahwa sistem yang dirancang dapat berfungsi dengan baik dan sesuai kebutuhan pengguna dengan persentase rata-rata sebesar 82,6\%.
\end{abstract}

Kata Kunci: Knowledge Management System, Knowledge Sharing, SECI

\section{PENDAHULUAN}

Universitas Tarumanagara atau UNTAR merupakan salah satu universitas swasta terbesar di Jakarta yang memiliki visi menjadi universitas entrepreneurial unggul yang memiliki integritas dan profesionalisme di Asia Tenggara. Dalam mewujudkan visi tersebut, salah satu upaya yang dilakukan adalah meningkatkan berbagai layanan teknologi informasi di lingkungan sivitas akademika UNTAR yang diharapkan mampu mendorong kemajuan UNTAR ke depannya.

UNTAR memiliki unit yang bergerak dalam bidang pengembangan perangkat lunak dan layanan teknologi informasi yang bernama Pusat Komputer. Unit tersebut dibawah Direktorat Sistem Informasi dan Database yang memiliki tugas dan tanggung jawab terhadap semua operasional dan pengembangan perangkat lunak serta layanan berbasis teknologi informasi di lingkungan sivitas akademika UNTAR.

Perlu diketahui bahwa pengembangan perangkat lunak di Pusat Komputer UNTAR dilakukan oleh tim pengembangan yang terdiri atas beberapa orang programmer. Programmer-programmer tersebut ada yang merupakan programmer senior dan ada yang merupakan programmer junior. Masing-masing memiliki latar belakang, coding model, serta pengalaman yang berbeda antara satu dengan lainnya. Perbedaan ini kemudian menimbulkan kesenjangan dari sisi pengetahuan dan pemahaman terhadap pekerjaan-pekerjaan yang dilakukan. Hal ini tentu dapat menjadi hambatan dalam aktifitas pekerjaan terkait pengembangan perangkat lunak di Pusat Komputer Universitas Tarumanagara. Ditambah lagi pengetahuan, pemahaman, serta pengalaman yang ada tidak terdokumentasi dan terdistribusi dengan baik diantara programmer sehingga ketika terjadi masalah turn-over programmer, pengetahuan, pemahaman, serta pengalaman tersebut hilang begitu saja.

Di sisi lain, pengetahuan merupakan aset yang dapat dikelola, dikomunikasikan serta di gunakan secara bersama [1]. Sehingga pengetahuan haruslah dapat dimanfaatkan seoptimal mungkin. Keuntungan 
utama penerapan Knowledge Management bagi organisasi adalah (1) adanya informasi pengetahuan yang lebih transparan, (2) terdapatnya proses penciptaan nilai tambah berbasis pengetahuan, (3) meningkatkan motivasi staf, (4) meningkatkan daya saing, serta (5) keamanan dan ketahanan organisasi untuk jangka panjang [2].

Dalam penulisan tesis ini pula, penulis telah melakukan studi literatur terhadap model-model yang digunakan dalam Knowledge Management berdasarkan analisis yang dilakukan oleh Chaeruman [3] memaparkan model konseptual Knowledge Management yaitu: (1) SECI, merupakan model yang diperkenalkan oleh Nonaka dan Takeuchi yang terdiri atas Tacit Knowledge dan Explicit Knowledge yang memiliki proses sosialisasi, eksternalisai, kombinasi dan internalisasi. SECI Model diimplementasikan dalam ruang lingkup Face-to-Face, Peer-to-Peer, Group-to-Group, dan On the Site. (2) Intelectual Capital, merupakan model yang diperkenalkan oleh Edvinsson yang terdiri atas Human Capital (Human resources, intellectual asset, intellectual property), Bussines Asset (Complementary Aset), Structural Capital (organizational asset, intangible asset). Untuk proses dan ruang lingkup implementasi bersifat implisit. (3) OK Net, model ini diperkenalkan oleh Carayannis yang terdiri dari State of Knowledge and state of Knowing (knowledge dan meta knowledge). Proses dari model ini meliputi Knowledge creation, Knowledge securing, knowledge distribution, Kniowldge retrieval. (4) Ecology of KM, model yang diperkenalkan oleh Snowden ini terdiri atas Explicit/Tacit Knowledge, Knowledge Asset, Trust, Decision. Proses yang ada di dalam model ini adalah Knowledge mapping, competency creation, tacit knowledge management, intellectual capital system. Ruang lingkup implementasi model ini bersifat implisit. (5) Taxonomy of KM, model ini diperkenalkan oleh Despres \& Chauval yang terdiri dari Tacit Knowledge dan Explicit Knowledge. Proses di dalam model ini yaitu Scan-map, capture-create, packagestore, share-apply, transforminnovate. Ruang lingkup implementasi dari model ini yaitu Implisit: on site dan virtual.

Berdasarkan uraian permasalahan serta studi literatur terhadap model-model Knowledge Management diatas, maka dapat dipahami bahwa pentingnya sebuah Knowledge Management System di dalam sebuah organisasi atau tim pengembangan guna mencapai suatu tujuan dalam mengelola pengetahuan dan sebagai media berbagi pengetahuan (Knowledge Sharing) antara programer-programmer dalam proses pengembangan perangkat lunak di Pusat Komputer UNTAR.

Alasan penulis menggunakan pendekatan SECI model dalam tesis ini adalah karena SECI model dinilai sesuai sebagai model Knowledge Management yang mendukung Knowledge Sharing, dimana SECI model dapat diterapkan di ruang lingkup Face-toFace, Peer-to-Peer, Group-to-Group, dan On the Site. Oleh karena itu penulis mengambil judul "Knowledge Management System dengan SECI Model Sebagai Media Knowledge Sharing di Pusat Komputer Universitas Tarumanagara".

\section{LANDASAN TEORI}

\subsection{Knowledge}

Davenport dan Prusak menyatakan bahwa "Knowledge is a fluid mix of framed experience, values, contextual information and expert insight that provides a framework for evaluating and incorporating new experiences and information" [4].

Dalam definisi lainnya, Becerra-Fernandez dan Sabherwal menyatakan bahwa "Knowledge is quite distinct from data and information, although the three terms are sometimes used interchangeably" [5].

Dari uraian beberapa definisi terkait knowledge diatas, maka dapat disimpulkan bahwa Knowledge merupakan kumpulan informasi, pengalaman, dan nilainilai yang dapat digunakan secara eksplisit.

\subsection{Jenis Knowledge}

Menurut Polanyi [6] ada dua jenis knowledge utama yaitu:

\section{a. Tacit knowledge}

Sulit untuk dikatakan dengan jelas dan sulit untuk di masukan dalam kata, teks, atau gambar biasanya ini seperti idea tau gagasan.

\section{b. Explicit Knowledge}

Isi gambaran yang telah di tangkap di beberapa bentuk nyata seperti kata, rekaman suara, atau gambar.

\subsection{Knowledge Management}

Knowledge Management mengembangkan sistem dan proses untuk mendapatkan dan berbagi aset kepandaian. Ini meningkatkan generasi berdasarkan kegunaan, dapat dipertanggungjawabkan, dan informasi penuh arti, dan mencari agar meningkatkan kedua hal, individu serta kelompok belajar.

Selain itu dapat memaksimalkan nilai dari sebuah dasar kepandaian organisasi melewati fungsi berbeda dan lokasi berbeda. Knowledge Management mengatur bahwa keberhasilan bisnis berupa koleksi bukan produk tapi dasar pengetahuan khusus. Kepandaian adalah kunci yang akan memberikan daya saing perusahaan [6].

Menurut Becerra-Fernandez dan Sabherwal [5] menyatakan bahwa Knowledge Management secara sederhana dapat didefinisikan sebagai tindakan terhadap apa yang dibutuhkan untuk mendapatkan hasil yang maksimal dari sumber pengetahuan. 
Sedangkan definisi lain, dinyatakan bahwa Knowledge Management merupakan isu strategis dalam organisasi yang dipercaya dapat meningkatkan kinerja organisasi [7].

\subsection{Strategi Penerapan Knowledge Management}

Tiwana [8] menjelaskan strategi penerapan $K M$ dengan memberikan dua alternative strategi yang focus pada pemanfaatn teknologi informasi, dua strategi tersebut yaitu:

\section{a. Strategi kodifikasi (Codification Strategi)}

Strategi penerapan Knowledge Management yang lebih menekankan pada pemanfaatan teknologi informasi sebagai alat pendukung karena premis yang diusung adalah semua pengetahuan terkodifikasi sebagai sumber pengetahuan.

b. Startegi personalisasi (Personalization strategi) Strategi yang lebih menekankan pada peran manusia sebagai sumber pengetahuan. Proses akuisisi, berbagi, pemanfaatan dan penyimpanan pengetahuan disini sangat mengandalkan manusia.

\subsection{Tahapan Penerapan Knowledge Management}

Amrit Tiwana [8] menjelaskan empat tahapan utama dalam penerapan knowledge management, tahapan-tahapan tersebut dapat dilihat pada gambar berikut

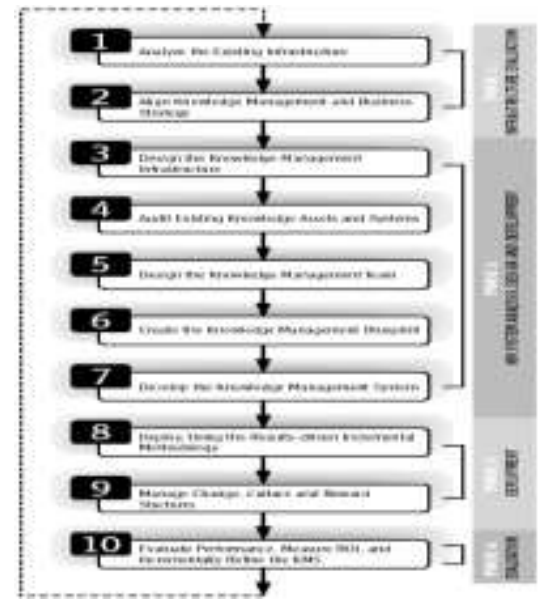

Gambar 1 The 10-Step of KM Road Map [8]

\subsection{Knowledge Sharing}

Knowledge Sharing adalah proses yang sistematis dalam mengirimkan, mendistribusikan dan mendiseminasikan pengetahuan dan konteks multidimensi dari seseorang atau organisasi kepada orang atau organisasi lain yang membutuhkan melalui metode dan media yang variatif [9].

Menurut Becerra-Fernandez dan Sabherwal [5] menyatakan bahwa "Knowledge sharing is the process through which explicit or tacit knowledge is communicated to other individuals".

Berdasarkan beberapa pendapat diatas mengenai knowledge sharing, dapat disimpulkan bahwa knowledge sharing merupakan proses berbagi ilmu, kemampuan, pengetahuan, maupun pengalaman dari individu ke individu, dari individu ke organisasi, ataupun dari organisasi ke individu sehingga menciptakan pengetahuan baru.

\subsection{SECI Model}

Menurut Nonaka dan Takeuchi [10] sebuah knowledge diciptakan melalui interaksi antara pengetahuan tacit dan eksplisit. Interaksi tersebut dikemukakan dalam empat fase konversi pengetahuan, yang diilustrasikan pada gambar 2 dibawah ini:

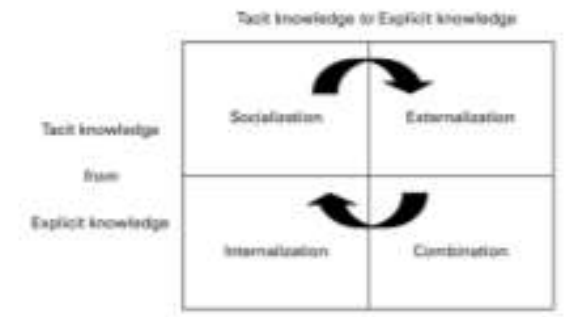

Gambar 2Error! No text of specified style in document. SECI Model [10]

a. Sosialisasi (Socialization)

Pada proses sosialisasi terjadi interaksi sosial antar individu sehngga terjadi interaksi antara pengetahuan tacit, umumnya bentuk proses sosialisasi adalah diskusi, cerita, ataupun sharing (berbagi) pengalaman

b. Eksternalisasi (externalization)

Merupakan proses pengubahan atau penerjemahan pengetahuan dalam bentuk tacit menjadi pengetahuan yang explicit (nyata), umumnya dalam bentuk tulisan ataupun gambar. Proses

c. Kombinasi (combination)

Penyebarluasan dan/atau pengembangan dari pengetahuan-pengetahuan eksplisit yang telah ada. Pengetahuan yang telah terdokumentasikan dapat disebarluaskan melalui suatu pertemuan dalam bentuk dokumen ataupun melalui suatu proses pendidikan atau pelatihan.

d. Internalisasi (internalization)

Perubahan pengetahuan explicit menjadi pengetahuan tacit, umum dilakukan melalui proses belajar dan/atau penelitian yang dilakukan ataupun pengalaman yang dilalui oleh setiap individu 


\section{METODOLOGI PENELITIAN}

Penelitian ini menggunakan metode penelitian kualitatif dengan pendekatan Action Research.

Dalam penelitian ini, dilakukan analisis-analisis untuk mendukung pembangunan dan penerapan Knowledge Management System, adapun analisis tersebut antara lain:

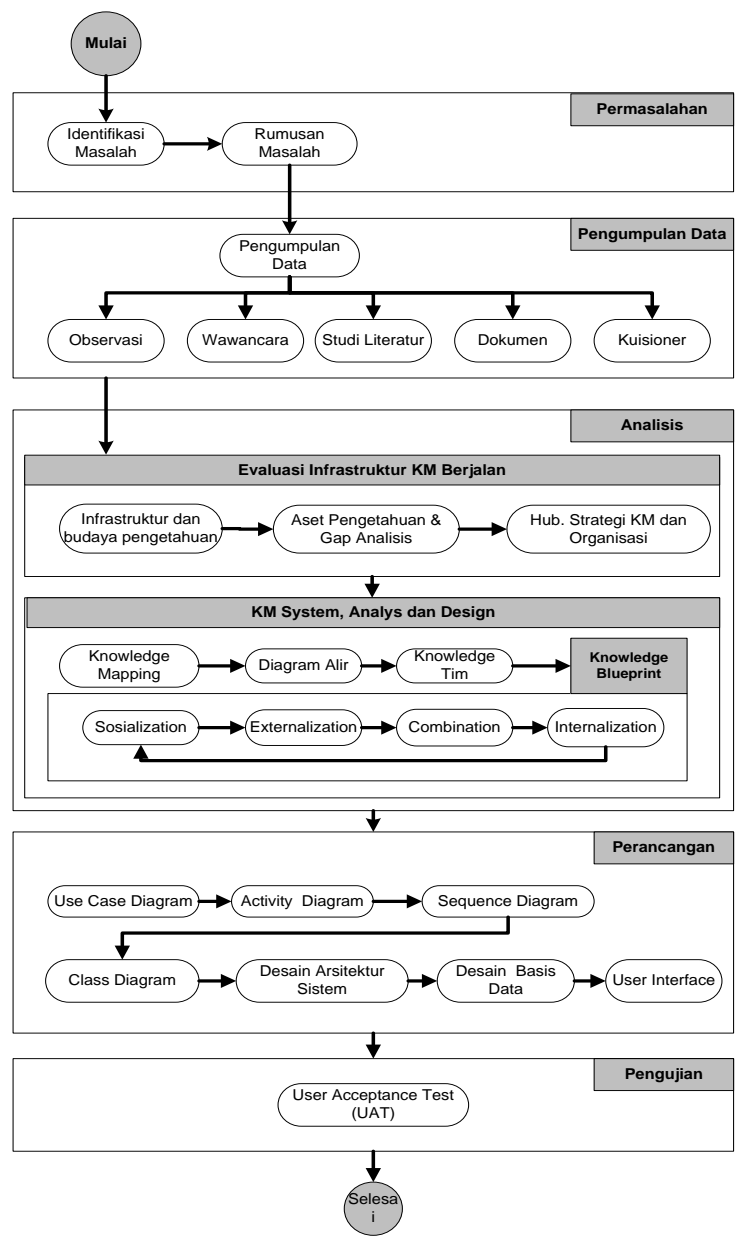

Gambar 3 Tahapan Penelitian

Berikut ini adalah penjelasan mengenai langkahlangkah diatas:

\section{a. Identifikasi Masalah}

Pada tahap ini dilakukan identifikasi masalah yang ada pada unit terkait. output dari langkah ini adalah research question atau rumusan masalah.

b. Pengumpulan Data

Research question atau rumusan masalah kemudian menjadi input pada tahap ini, proses yang dilakukan selanjutnya adalah pengumpulan data berupa observasi, wawancara, pengumpulan dokumen terkait dan studi literatur yang berkaitan dengan rumusan masalah.

\section{c. Analisis}

Hasil pengumpulan data pada tahap sebelumnya menjadi input pada tahap ini, kemudian dilakukan analisis yang meliputi analisis infrastruktur terkini, analisis hubungan antara strategi organisasi dan strategi $K M$, analisis knowledge gap, analisis infrastruktur $K M$ usulan, analisis asset pengetahuan, analisis knowledge management tim, dan analisis knowledge management blue print

\section{d. Perancangan}

Dari hasil analisis, kemudian dilakukan perancangan sistem yang meliputi use case diagram, activity diagram, class diagram, desain arsitektur sistem, desain basis data hingga desain user interface

\section{e. Pengujian}

Proses pengujian kemudian dilakukan terhadap sistem menggunakan metode User Acceptance Test sebagai uji validitas perangkat lunak.

\section{HASIL DAN PEMBAHASAN}

Pada bab ini menjelaskan hasil analisis yang telah dilakukan berdasarkan pengolahan data yang diperoleh hingga membuat model solusi knowledge management, rancangan knowledge management system, serta pengujian hasil rancangan.

\subsection{Infrastruktur Teknologi}

Berdasarkan dokumen blue print sistem informasi yang di miliki oleh bagian Pusat Komputer serta hasil wawancara terkait infrstruktur yang berjalan saat ini dapat diketahui bahwa infrastruktur netwok dan server yang berjalan saat ini di Universitas Tarumanagara dapat dijelaskan bahwa server dibagi menjadi 3 bagian, yaitu yang pertama $D M Z$ sebagai server yang menyediakan layanan Web Hosting dan Email, yang kedua Server Farm merupakan server yang menyediakan layanan database utama dari aplikasi akademik dan aplikasi keuangan, yang ketiga Server Development merupakan server yang menyediakan layanan pengembangan aplikasi sebelum dijalankan di server utama.

Adapun untuk jaringan internet, Universitas Tarumanagara memiliki jaringan LAN dan Wifi yang tersebar di lingkungan Universitas Tarumanagara. Jaringan tersebut dimanfaatkan untuk keperluan kemudahan akses berbagai layanan yang tersedia baik bagi mahasiswa, dosen, karyawan, pimpinan dan lingkungan civitas akademika Universitas Tarumanagara.

\subsection{Budaya Pengetahuan}

Pemetaan budaya pengetahuan di Pusat Komputer Universitas Tarumanagara didapat dari hasil instrumen kuisioner. 
Adapun hasil kuisioner dari pentingnya pengetahuan dapat dilihat pada gambar grafik berikut

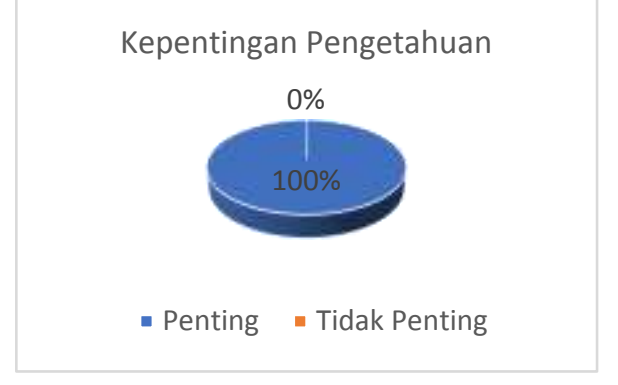

Gambar 4 Grafik Kepentingan Pengetahuan

Terkait dengan sumber pencarian pengetahuan yang sering digunakan, dapat dilihat pada gambar grafik berikut

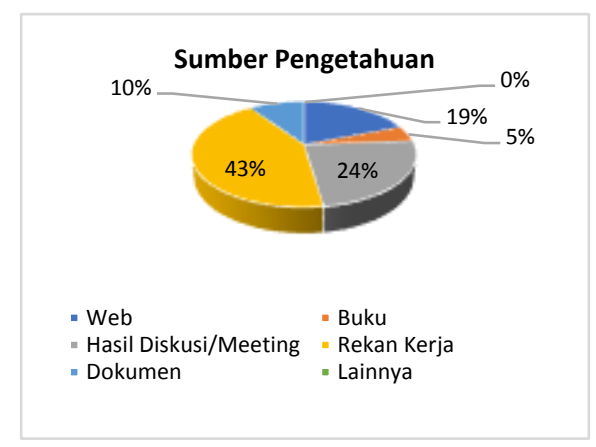

Gambar 5 Grafik Sumber Pengetahuan

Dari gambar grafik diatas, diketahui bahwa sumber pengetahuan yang sering digunakan yaitu rekan kerja sebesar 43\%, sedangkan hasil diskusi atau meeting sebesar $24 \%$, web sebesar $19 \%$, dokumen sebesar $10 \%$ dan buku sebesar 5\%.Selanjutnya, terkait hasil kuisioner tentang berbagi pengetahuan dapat di lihat pada gambar grafik berikut

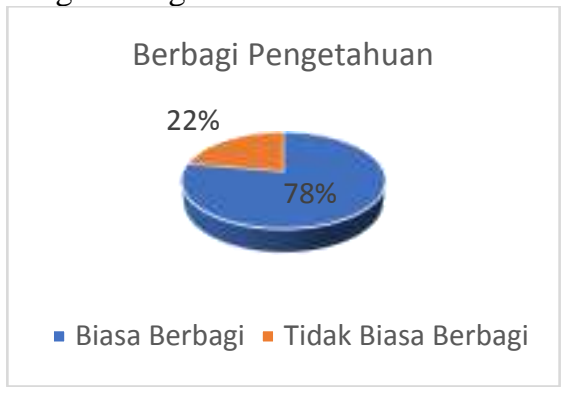

Gambar 6 Grafik Berbagi Pengetahuan

Dari gambar diatas dapat diketahui bahwa karyawan di Pusat Komputer Universitas Tarumanagara yang biasa berbagi pengetahuan yaitu sebesar $78 \%$, sedang yang tidak biasa berbagi sebesar $22 \%$.

\subsection{Business Process}

Berdasarkan hasil wawancara telah di identifikasi proses bisnis yang terjadi di Pusat Komputer Universitas Tarumanagara khususnya pada bagian pengembangan perangkat lunak. Bisnis proses yang terjadi di bagian pengembangan perangkat lunak di Pusat Komputer Universitas Tarumanagara yaitu pembuatan website, pembuatan program layanan akademik, pembuatan program layanan kemahasiswaan, pembuatan program layanan kedosenan, pembuatan program layanan kepegawaian, pembuatan program uang kuliah dan pembuatan email.

\subsection{Knowledge Assets}

Pada analisis aset pengetahuan meliputi identifikasi pengetahuan dan identifikasi ahli yang akan menjadi sumber daya bagi knowledge management system yang dibangun.

Adapun pengetahuan-pengetahuan yang dapat dijadikan sumber dalam Knowledge Management System ini diuraikan pada tabel 1 sebagai berikut

Tabel 1 Aset Pengetahuan

\begin{tabular}{|c|c|c|c|c|c|}
\hline $\begin{array}{l}\mathbf{N} \\
\mathbf{0}\end{array}$ & $\begin{array}{l}\text { Penget } \\
\text { ahuan }\end{array}$ & $\begin{array}{c}\text { Pembu } \\
\text { at }\end{array}$ & $\begin{array}{l}\text { For } \\
\text { mat }\end{array}$ & $\begin{array}{c}\text { Lokasi } \\
\text { Sumbe } \\
\text { r } \\
\text { Penget } \\
\text { ahuan }\end{array}$ & $\begin{array}{c}\text { Pengg } \\
\text { una }\end{array}$ \\
\hline \multicolumn{6}{|c|}{ Pengetahuan yang sudah terdapat di organisasi } \\
\hline 1 & $\begin{array}{l}\text { Penget } \\
\text { ahuan } \\
\text { Proga } \\
\text { mming } \\
\text { PHP }\end{array}$ & $\begin{array}{l}\text { Bag. } \\
\text { Penge } \\
\text { mbanga } \\
\text { n }\end{array}$ & $\begin{array}{l}\text { Sour } \\
\text { ce } \\
\text { code }\end{array}$ & $\begin{array}{l}\text { Dir. } \\
\text { SIDB / } \\
\text { Pusko } \\
\text { m }\end{array}$ & $\begin{array}{l}\text { Bag. } \\
\text { Penge } \\
\text { mbang } \\
\text { an }\end{array}$ \\
\hline 2 & $\begin{array}{l}\text { Penget } \\
\text { ahuan } \\
\text { Progra } \\
\text { mming } \\
\text { ASP.N } \\
\text { et VB }\end{array}$ & $\begin{array}{l}\text { Bag. } \\
\text { Penge } \\
\text { mbanga } \\
n\end{array}$ & $\begin{array}{l}\text { Sour } \\
\text { ce } \\
\text { code }\end{array}$ & $\begin{array}{l}\text { Dir. } \\
\text { SIDB / } \\
\text { Pusko } \\
\text { m }\end{array}$ & $\begin{array}{l}\text { Bag. } \\
\text { Penge } \\
\text { mbang } \\
\text { an }\end{array}$ \\
\hline 3 & $\begin{array}{l}\text { Penget } \\
\text { ahuan } \\
\text { Progra } \\
\text { mming } \\
\text { HTML }\end{array}$ & $\begin{array}{l}\text { Bag. } \\
\text { Penge } \\
\text { mbanga } \\
n\end{array}$ & $\begin{array}{l}\text { Sour } \\
\text { ce } \\
\text { code }\end{array}$ & $\begin{array}{l}\text { Dir. } \\
\text { SIDB / } \\
\text { Pusko } \\
\text { m }\end{array}$ & $\begin{array}{l}\text { Bag. } \\
\text { Penge } \\
\text { mbang } \\
\text { an }\end{array}$ \\
\hline 4 & $\begin{array}{l}\text { Penget } \\
\text { ahuan } \\
\text { Progra } \\
\text { mming } \\
\text { Javascr } \\
\text { ipt }\end{array}$ & $\begin{array}{l}\text { Bag. } \\
\text { Penge } \\
\text { mbanga } \\
\text { n }\end{array}$ & $\begin{array}{l}\text { Sour } \\
\text { ce } \\
\text { code }\end{array}$ & $\begin{array}{l}\text { Dir. } \\
\text { SIDB / } \\
\text { Pusko } \\
\text { m }\end{array}$ & $\begin{array}{l}\text { Bag. } \\
\text { Penge } \\
\text { mbang } \\
\text { an }\end{array}$ \\
\hline 5 & $\begin{array}{l}\text { Penget } \\
\text { ahuan } \\
\text { Progra }\end{array}$ & $\begin{array}{l}\text { Bag. } \\
\text { Penge }\end{array}$ & $\begin{array}{l}\text { Sour } \\
\text { ce } \\
\text { code } \\
\end{array}$ & $\begin{array}{l}\text { Dir. } \\
\text { SIDB / }\end{array}$ & $\begin{array}{l}\text { Bag. } \\
\text { Penge }\end{array}$ \\
\hline
\end{tabular}




\begin{tabular}{|c|c|c|c|c|c|}
\hline & $\begin{array}{l}\text { mming } \\
\text { CSS }\end{array}$ & $\begin{array}{l}\text { mbanga } \\
\mathrm{n}\end{array}$ & & $\begin{array}{l}\text { Pusko } \\
\mathrm{m}\end{array}$ & $\begin{array}{l}\text { mbang } \\
\text { an }\end{array}$ \\
\hline 6 & $\begin{array}{l}\text { Penget } \\
\text { ahuan } \\
\text { Databa } \\
\text { se SQL } \\
\text { Server } \\
\end{array}$ & $\begin{array}{l}\text { Bag. } \\
\text { Penge } \\
\text { mbanga } \\
n\end{array}$ & $\begin{array}{l}\text { Sour } \\
\text { ce } \\
\text { code }\end{array}$ & $\begin{array}{l}\text { Dir. } \\
\text { SIDB / } \\
\text { Pusko } \\
\mathrm{m}\end{array}$ & $\begin{array}{l}\text { Bag. } \\
\text { Penge } \\
\text { mbang } \\
\text { an }\end{array}$ \\
\hline 7 & $\begin{array}{l}\text { Penget } \\
\text { ahuan } \\
\text { Databa } \\
\text { se } \\
\text { MySQ } \\
\text { L }\end{array}$ & $\begin{array}{l}\text { Bag. } \\
\text { Penge } \\
\text { mbanga } \\
n\end{array}$ & $\begin{array}{l}\text { Sour } \\
\text { ce } \\
\text { code }\end{array}$ & $\begin{array}{l}\text { Dir. } \\
\text { SIDB / } \\
\text { Pusko } \\
\mathrm{m}\end{array}$ & $\begin{array}{l}\text { Bag. } \\
\text { Penge } \\
\text { mbang } \\
\text { an }\end{array}$ \\
\hline 8 & $\begin{array}{l}\text { Penget } \\
\text { ahuan } \\
\text { Databa } \\
\text { se } \\
\text { Informi } \\
x\end{array}$ & $\begin{array}{l}\text { Bag. } \\
\text { Penge } \\
\text { mbanga } \\
n\end{array}$ & $\begin{array}{l}\text { Sour } \\
\text { ce } \\
\text { code }\end{array}$ & $\begin{array}{l}\text { Dir. } \\
\text { SIDB / } \\
\text { Pusko } \\
\mathrm{m}\end{array}$ & $\begin{array}{l}\text { Bag. } \\
\text { Penge } \\
\text { mbang } \\
\text { an }\end{array}$ \\
\hline 9 & $\begin{array}{l}\text { Penget } \\
\text { ahuan } \\
\text { masala } \\
\mathrm{h} \\
\text { akade } \\
\text { mik }\end{array}$ & $\begin{array}{l}\text { Biro } \\
\text { Adak }\end{array}$ & $\begin{array}{l}\text { Dok } \\
\text { ume } \\
n\end{array}$ & $\begin{array}{l}\text { Dir. } \\
\text { Pembel } \\
\text { ajaran }\end{array}$ & $\begin{array}{l}\text { Unit } \\
\text { Terkait }\end{array}$ \\
\hline $\begin{array}{l}1 \\
0\end{array}$ & $\begin{array}{l}\text { Penget } \\
\text { ahuan } \\
\text { masala } \\
\mathrm{h} \\
\text { kemah } \\
\text { asiswa } \\
\text { an } \\
\end{array}$ & $\begin{array}{l}\text { Biro } \\
\text { Kemah } \\
\text { asiswaa } \\
\mathrm{n}\end{array}$ & $\begin{array}{l}\text { Dok } \\
\text { ume } \\
n\end{array}$ & $\begin{array}{l}\text { Dir. } \\
\text { Kemah } \\
\text { asiswaa } \\
\mathrm{n}\end{array}$ & $\begin{array}{l}\text { Unit } \\
\text { Terkait }\end{array}$ \\
\hline $\begin{array}{l}1 \\
1\end{array}$ & $\begin{array}{l}\text { Penget } \\
\text { ahuan } \\
\text { masala } \\
\mathrm{h} \\
\text { kedose } \\
\text { nan }\end{array}$ & $\begin{array}{l}\text { Biro } \\
\text { Persona } \\
\text { lia }\end{array}$ & $\begin{array}{l}\text { Dok } \\
\text { ume } \\
n\end{array}$ & $\begin{array}{l}\text { Dir. } \\
\text { Mutu \& } \\
\text { Sumber } \\
\text { daya }\end{array}$ & $\begin{array}{l}\text { Unit } \\
\text { Terkait }\end{array}$ \\
\hline $\begin{array}{l}1 \\
2\end{array}$ & $\begin{array}{l}\text { Penget } \\
\text { ahuan } \\
\text { masala } \\
\mathrm{h} \\
\text { kepega } \\
\text { waian } \\
\end{array}$ & $\begin{array}{l}\text { Biro } \\
\text { Persona } \\
\text { lia }\end{array}$ & $\begin{array}{l}\text { Dok } \\
\text { ume } \\
n\end{array}$ & $\begin{array}{l}\text { Dir. } \\
\text { Mutu \& } \\
\text { Sumber } \\
\text { daya }\end{array}$ & $\begin{array}{l}\text { Unit } \\
\text { Terkait }\end{array}$ \\
\hline $\begin{array}{l}1 \\
3\end{array}$ & $\begin{array}{l}\text { Inform } \\
\text { asi } \\
\text { SOP }\end{array}$ & $\begin{array}{l}\text { Biro } \\
\text { Rektora } \\
\mathrm{t}\end{array}$ & $\begin{array}{l}\text { Dok } \\
\text { ume } \\
n\end{array}$ & $\begin{array}{l}\text { Rektora } \\
\mathrm{t}\end{array}$ & $\begin{array}{l}\text { Unit } \\
\text { Terkait }\end{array}$ \\
\hline $\begin{array}{l}1 \\
4\end{array}$ & $\begin{array}{l}\text { Inform } \\
\text { asi } \\
\text { aturan- } \\
\text { aturan }\end{array}$ & $\begin{array}{l}\text { Biro } \\
\text { Rektora } \\
\mathrm{t}\end{array}$ & $\begin{array}{l}\text { Dok } \\
\text { ume } \\
n\end{array}$ & $\begin{array}{l}\text { Rektora } \\
\mathrm{t}\end{array}$ & $\begin{array}{l}\text { Unit } \\
\text { Terkait }\end{array}$ \\
\hline $\begin{array}{l}1 \\
5\end{array}$ & $\begin{array}{l}\text { Manual } \\
\text { Book } \\
\text { Aplika } \\
\text { si } \\
\end{array}$ & $\begin{array}{l}\text { Bag. } \\
\text { Penge } \\
\text { mbanga } \\
\mathrm{n} \\
\end{array}$ & $\begin{array}{l}\text { Dok } \\
\text { ume } \\
n\end{array}$ & $\begin{array}{l}\text { Dir. } \\
\text { SIDB/P } \\
\text { uskom }\end{array}$ & $\begin{array}{l}\text { Unit } \\
\text { terkait }\end{array}$ \\
\hline
\end{tabular}

\begin{tabular}{|c|c|c|c|c|c|}
\hline $\begin{array}{l}1 \\
6\end{array}$ & $\begin{array}{l}\text { Bug } \\
\text { Report }\end{array}$ & $\begin{array}{l}\text { Bag. } \\
\text { Penge } \\
\text { mbanga }\end{array}$ & $\begin{array}{l}\text { Rep } \\
\text { ort }\end{array}$ & $\begin{array}{l}\text { Dir. } \\
\text { SIDB/P } \\
\text { uskom }\end{array}$ & $\begin{array}{l}\text { Bag. } \\
\text { Penge } \\
\text { mbang }\end{array}$ \\
\hline
\end{tabular}

Adapun ahli-ahli (expert) yang dapat dijadikan sumber pengetahuan dalam Knowledge Management System ini ditampilkan dalam tabel sebagai berikut:

\begin{tabular}{|c|l|l|l|}
\multicolumn{5}{|c|}{ Tabel 2 Identifikasi Ahli } \\
$\begin{array}{c}\text { N } \\
\mathbf{0}\end{array}$ & Nama Ahli & $\begin{array}{l}\text { Bidang } \\
\text { Pengetahuan }\end{array}$ & Jabatan \\
\hline 1 & $\begin{array}{l}\text { Ahmad } \\
\text { Hulaliyah, } \\
\text { S.Kom., } \\
\text { M.Kom }\end{array}$ & $\begin{array}{l}\text { Pengembanga } \\
\text { n sistem, } \\
\text { programming }\end{array}$ & $\begin{array}{l}\text { Kepala } \\
\text { Pusat } \\
\text { Komputer }\end{array}$ \\
\hline 2 & $\begin{array}{l}\text { Muhadi } \\
\text { Hariyanto, } \\
\text { S.Kom., } \\
\text { M.Kom }\end{array}$ & $\begin{array}{l}\text { Programming } \\
\text { and system } \\
\text { analysis }\end{array}$ & $\begin{array}{l}\text { Programme } \\
\text { r senior }\end{array}$ \\
\hline 3 & $\begin{array}{l}\text { Retno } \\
\text { Wahyuningsi } \\
\text { h, S.Kom }\end{array}$ & Programming & $\begin{array}{l}\text { Programme } \\
\text { r Senior }\end{array}$ \\
\hline 4 & Nurwahyudi & $\begin{array}{l}\text { Server dan } \\
\text { network } \\
\text { administrator }\end{array}$ & $\begin{array}{l}\text { Kepala } \\
\text { urusan } \\
\text { bagian } \\
\text { server }\end{array}$ \\
\hline
\end{tabular}

\subsection{Knowledge Gap}

Identifikasi knowledge gap (kesenjangan pengetahuan) digunakan untuk mengetahui keadaan pengetahuan saat ini dan yang dibutuhkan. Dalam identifikasi ini akan menghitung selisih antara nilai tingkat kepentingan dengan nilai tingkat penguasaaan.

Tabel 3 Perbandingan Tingkat Kepentingan dan Penguasaan Pengetahuan

\begin{tabular}{|c|c|c|c|c|c|c|c|c|c|c|c|c|c|c|}
\hline \multirow{2}{*}{$\begin{array}{l}\mathbf{N} \\
\mathbf{0}\end{array}$} & \multirow{2}{*}{$\begin{array}{c}\text { Kno } \\
\text { wled } \\
\text { ge }\end{array}$} & \multicolumn{6}{|c|}{$\begin{array}{c}\text { Tingkat } \\
\text { Kepentingan }\end{array}$} & \multicolumn{6}{|c|}{$\begin{array}{c}\text { Tingkat } \\
\text { Penguasaan }\end{array}$} & \multirow[t]{2}{*}{$\mathbf{G}$} \\
\hline & & 1 & 2 & 3 & 4 & 5 & $\mathbf{N}$ & 1 & 2 & 3 & 4 & 5 & $\mathbf{N}$ & \\
\hline 1 & $\begin{array}{l}\text { Peng } \\
\text { etahu } \\
\text { an } \\
\text { Prog } \\
\text { ammi } \\
n g \\
\text { PHP }\end{array}$ & 0 & 0 & 3 & 0 & 6 & 3 & 3 & 0 & 0 & 3 & 3 & $\begin{array}{l}3 \\
3\end{array}$ & 1 \\
\hline 2 & $\begin{array}{l}\text { Peng } \\
\text { etahu } \\
\text { an } \\
\text { Prog } \\
\text { ram } \\
\text { ming } \\
\text { ASP. } \\
\text { Net } \\
V B\end{array}$ & 0 & 0 & 1 & 2 & 6 & 4 & 3 & 1 & 2 & 0 & 3 & $\begin{array}{l}2 \\
8\end{array}$ & $\begin{array}{l}1, \\
7\end{array}$ \\
\hline
\end{tabular}




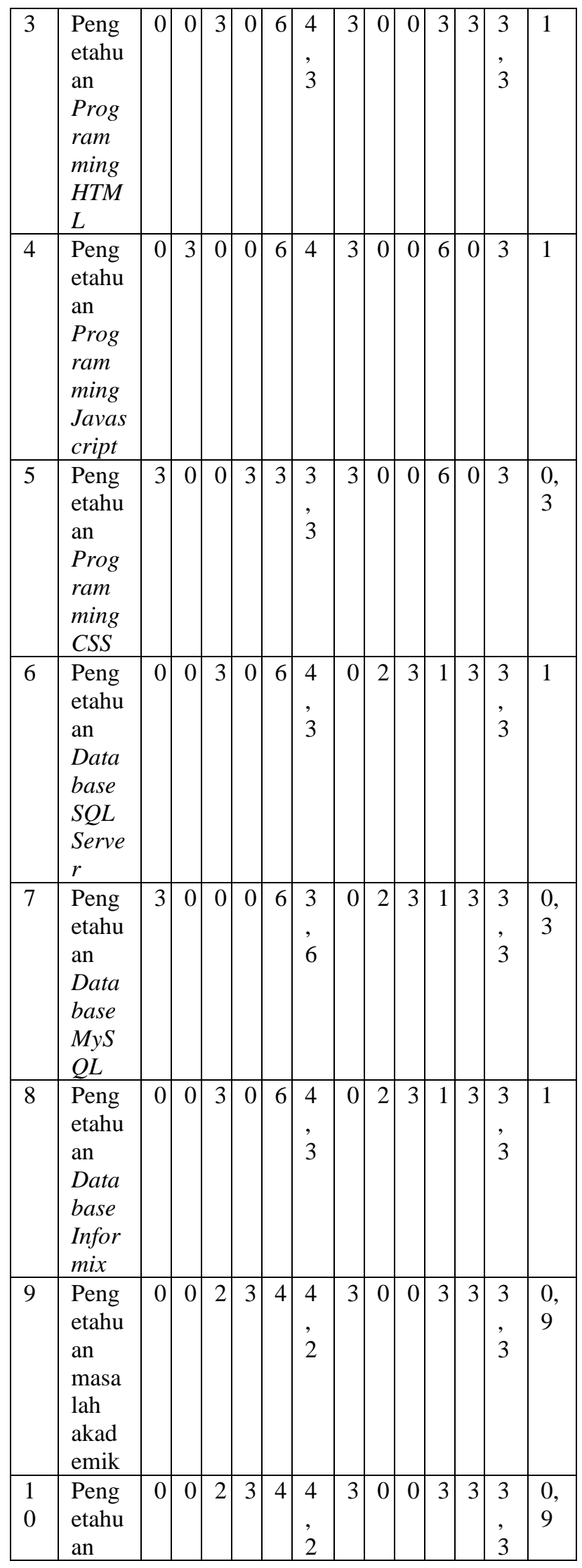

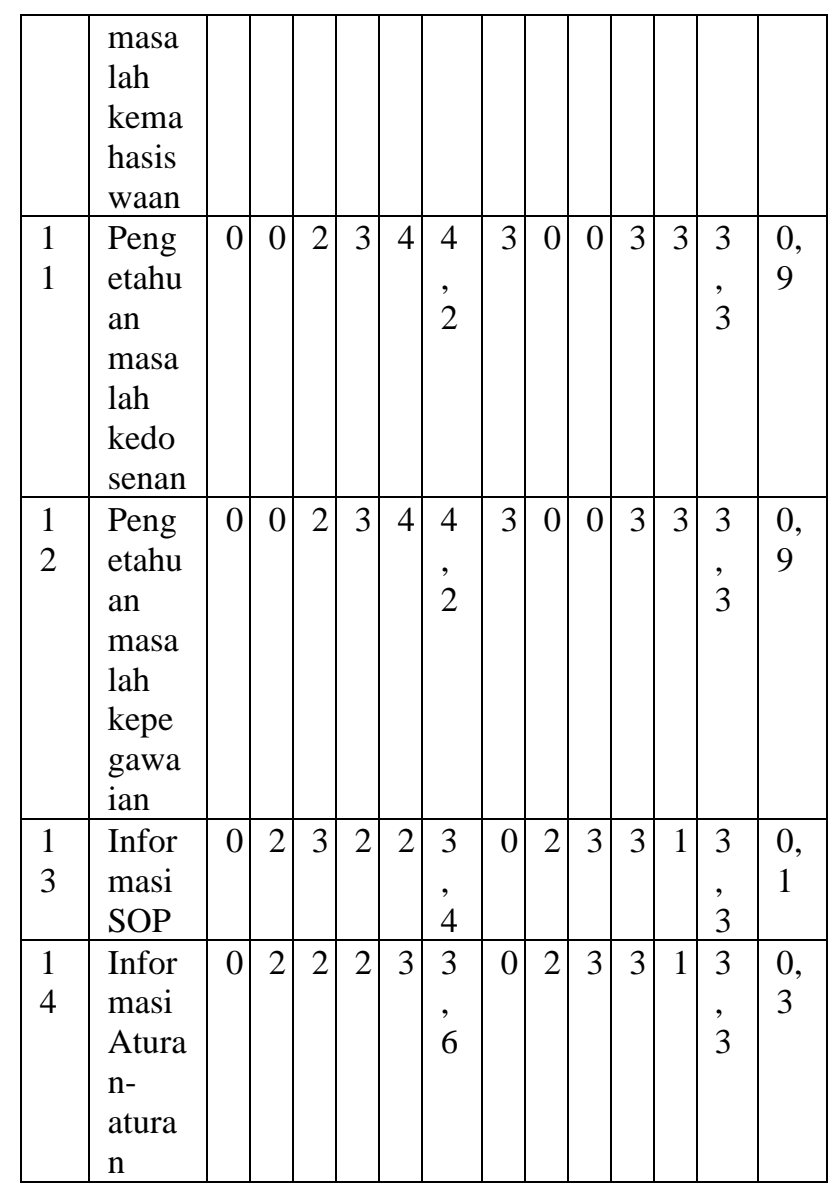

Dari uraian diatas dapat diketahui bahwa knowledge dengan $K$-Gap tertinggi yaitu pengetahuan seputar pemrograman ASP.Net sedangkan knowledge yang lain berada pada kisaran 0,1 hinga 1 .

\subsection{Analisis Strategi}

Pada tahap ini akan menjelaskan mengenai strategi organisasi, strategi knowledge management serta hubungan antara strategi organisasi dengan strategi knowledge management.

\section{a. Strategi Organisasi}

Sebagaimana telah dijelaskan sebelumnya, bahwa proses bisnis yang terjadi di Pusat Komputer Universitas Tarumanagara dominan dalam hal pengembangan perangkat lunak, karena itu dalam blue print sistem informasi Pusat Komputer Universitas Tarumanagara tahun 2016-2022 juga disebutkan tujuan yang ingin dicapai adalah membangun sistem informasi yang dapat diakses oleh semua civitas akademika yang mencakup sistem informasi untuk dosen, karyawan, mahasiswa, pimpinan, dan orang tua, dan penerapan teknologi informasi yang efektif untuk mendukung dan meningkatkan mutu kegiatankegiatan Tridarma di Universitas Tarumanagara. Berdasarkan hal tersebut, maka dapat di ketahui 
bahwa strategi bisnis yang diterapkan adalah Strategi Low Cost (cost leadership). Ini dapat terlihat dari proses bisnis yang dijalankan, dimana setiap proses menekankan pada sumber daya yang dimiliki yaitu para programmer sebagai pengembang perangkat lunak di Pusat Komputer Universitas Tarumanagara. Setiap produk yang dihasilkan merupakan produk perangkat lunak yang dikembangkan sendiri, sehingga dapat menekan biaya pembuatan perangkat lunak.

\section{b. Strategi $K M$}

Dalam hal strategi $K M$, dilakukan identifikasi melalui pengisian kusioner dengan beberapa pertanyaan strategis terkait KM. Adapun hasil identifikasi tersebut dapat terlihat pada tabel 4 berikut Tabel 4 Identifikasi Strategi KM

\begin{tabular}{|c|c|c|c|c|c|}
\hline $\begin{array}{l}\mathbf{N} \\
\mathbf{0}\end{array}$ & $\begin{array}{l}\text { Pertany } \\
\text { aan }\end{array}$ & Kodifikasi & $\begin{array}{c}\text { Bo } \\
\text { bot } \\
(\%) \\
)\end{array}$ & $\begin{array}{l}\text { Personali } \\
\text { sasi }\end{array}$ & $\begin{array}{c}\text { Bo } \\
\text { bot } \\
(\%) \\
\text { ) }\end{array}$ \\
\hline 1 & $\begin{array}{l}\text { Berada } \\
\text { dalam } \\
\text { tipe } \\
\text { bisnis } \\
\text { seperti } \\
\text { apa } \\
\text { perusaha } \\
\text { an } \\
\text { Anda? }\end{array}$ & $\begin{array}{l}\text { Menyedia } \\
\text { kan } \\
\text { layanan } \\
\text { dengan } \\
\text { kualitas } \\
\text { tinggi, bisa } \\
\text { diandalkan } \\
\text {, cepat dan } \\
\text { efektif } \\
\text { dalam } \\
\text { biaya. }\end{array}$ & 40 & $\begin{array}{l}\text { Menyedia } \\
\text { kan } \\
\text { produk } \\
\text { dan } \\
\text { layanan } \\
\text { yang } \\
\text { kreatif, } \\
\text { ketat, dan } \\
\text { bisa di } \\
\text { kostumisa } \\
\text { si. }\end{array}$ & 60 \\
\hline 2 & $\begin{array}{l}\text { Berapa } \\
\text { banyak } \\
\text { material } \\
\text { lama } \\
\text { seperti } \\
\text { data } \\
\text { proyek } \\
\text { dimasa } \\
\text { lalu, } \\
\text { dokume } \\
\text { n yang } \\
\text { ada } \\
\text { sekarang } \\
\text { dan } \\
\text { proyek } \\
\text { yang ter- } \\
\text { arsip } \\
\text { yang } \\
\text { anda } \\
\text { gunakan } \\
\text { kembali } \\
\text { sebagai } \\
\text { bagian } \\
\text { dari }\end{array}$ & $\begin{array}{l}\text { Anda } \\
\text { mengguna } \\
\text { kan } \\
\text { kembali } \\
\text { dokumen } \\
\text { lama } \\
\text { untuk } \\
\text { membuat } \\
\text { dokumen } \\
\text { baru. Anda } \\
\text { mengguna } \\
\text { kan } \\
\text { produk } \\
\text { yang ada } \\
\text { sekarang } \\
\text { untuk } \\
\text { membuat } \\
\text { produk } \\
\text { baru. Anda } \\
\text { mengetahu } \\
\text { i bahwa } \\
\text { setiap kali } \\
\text { harus } \\
\text { men- } \\
\text { deliver }\end{array}$ & 60 & $\begin{array}{l}\text { Setiap } \\
\text { masalah } \\
\text { mempuny } \\
\text { ai } \\
\text { kesempata } \\
\text { n untuk } \\
\text { menjadi } \\
\text { sebuah } \\
\text { "one off" } \\
\text { dan } \\
\text { masalah } \\
\text { yang unik. } \\
\text { Solusi } \\
\text { yang } \\
\text { kreatif } \\
\text { sering } \\
\text { menjadi } \\
\text { sesuatu } \\
\text { yang } \\
\text { sering } \\
\text { digunakan } \\
\text {. }\end{array}$ & 40 \\
\hline
\end{tabular}

\begin{tabular}{|c|c|c|c|c|c|}
\hline $\begin{array}{l}\mathbf{N} \\
\mathbf{0}\end{array}$ & $\begin{array}{l}\text { Pertany } \\
\text { aan }\end{array}$ & Kodifikasi & $\begin{array}{c}\text { Bo } \\
\text { bot } \\
(\% \\
)\end{array}$ & $\begin{array}{l}\text { Personali } \\
\text { sasi }\end{array}$ & $\begin{array}{c}\text { Bo } \\
\text { bot } \\
(\% \\
)\end{array}$ \\
\hline & $\begin{array}{l}\text { proyek } \\
\text { baru? }\end{array}$ & $\begin{array}{l}\text { sesuatu } \\
\text { kepada } \\
\text { pelanggan, } \\
\text { anda tidak } \\
\text { harus } \\
\text { membuatn } \\
\text { ya dari } \\
\text { awal. }\end{array}$ & & & \\
\hline 3 & $\begin{array}{l}\text { Model } \\
\text { pemberi } \\
\text { an harga } \\
\text { seperti } \\
\text { apa } \\
\text { untuk } \\
\text { produk } \\
\text { atau } \\
\text { layanan } \\
\text { yang } \\
\text { disediak } \\
\text { an } \\
\text { perusaha } \\
\text { an } \\
\text { Anda? }\end{array}$ & $\begin{array}{l}\text { Kompetisi } \\
\text { berbasis } \\
\text { harga }\end{array}$ & 50 & $\begin{array}{l}\text { Harga } \\
\text { berdasarka } \\
\mathrm{n} \\
\text { keahlian. } \\
\text { Penetapan } \\
\text { harga } \\
\text { tinggi } \\
\text { tidak akan } \\
\text { merugikan } \\
\text { bisnis } \\
\text { Anda. }\end{array}$ & 50 \\
\hline 4 & $\begin{array}{l}\text { Bagaima } \\
\text { na } \\
\text { tentang } \\
\text { margin } \\
\text { keuntun } \\
\text { gan } \\
\text { perusaha } \\
\text { an } \\
\text { Anda? }\end{array}$ & $\begin{array}{l}\text { Keuntunga } \\
\text { n sedikit, } \\
\text { keuntunga } \\
\text { n besar } \\
\text { didapat } \\
\text { dari omset } \\
\text { penjualan } \\
\text { yang } \\
\text { banyak. }\end{array}$ & 50 & $\begin{array}{l}\text { Margin } \\
\text { keuntunga } \\
\text { n yang } \\
\text { sangat } \\
\text { tinggi }\end{array}$ & 50 \\
\hline 5 & $\begin{array}{l}\text { Bagaima } \\
\text { na anda } \\
\text { bisa } \\
\text { menjelas } \\
\text { kan } \\
\text { tentang } \\
\text { peranan } \\
\text { IT dalam } \\
\text { memain } \\
\text { kan } \\
\text { peran } \\
\text { dalam } \\
\text { proses } \\
\text { pekerjaa } \\
\text { n di } \\
\text { perusaha } \\
\text { an } \\
\text { Anda? }\end{array}$ & $\begin{array}{l}\text { IT adalah } \\
\text { pendorong } \\
\text { utama, } \\
\text { tujuannya } \\
\text { adalah } \\
\text { untuk } \\
\text { menghubu } \\
\text { ngkan } \\
\text { orang } \\
\text { yang } \\
\text { tersebar di } \\
\text { perusahaa } \\
\text { n dengan } \\
\text { pengetahu } \\
\text { an } \\
\text { terkodifika } \\
\text { si } \\
\text { (misalnya } \\
\text { laporan, } \\
\text { dokumenta }\end{array}$ & 70 & $\begin{array}{l}\text { Penyimpa } \\
\text { nan dan } \\
\text { pengakses } \\
\text { an } \\
\text { kembali } \\
\text { data } \\
\text { bukanlah } \\
\text { aplikasi } \\
\text { utama dari } \\
\text { IT. IT } \\
\text { dipertimba } \\
\text { ngkan } \\
\text { sebagai } \\
\text { pendorong } \\
\text { untuk } \\
\text { komunika } \\
\text { si, aplikasi } \\
\text { seperti } \\
\text { email dan } \\
\text { video }\end{array}$ & 30 \\
\hline
\end{tabular}




\begin{tabular}{|c|c|c|c|c|c|}
\hline $\begin{array}{l}\mathbf{N} \\
\mathbf{0}\end{array}$ & $\begin{array}{l}\text { Pertany } \\
\text { aan }\end{array}$ & Kodifikasi & $\begin{array}{c}\text { Bo } \\
\text { bot } \\
(\%) \\
)\end{array}$ & $\begin{array}{l}\text { Personali } \\
\text { sasi }\end{array}$ & $\begin{array}{c}\text { Bo } \\
\text { bot } \\
(\%) \\
)\end{array}$ \\
\hline & & $\begin{array}{l}\text { si, kode } \\
\text { dll) dalam } \\
\text { sebuah } \\
\text { form yang } \\
\text { bisa } \\
\text { digunakan } \\
\text { ulang. }\end{array}$ & & $\begin{array}{l}\text { conferenci } \\
n g \\
\text { dipertimba } \\
\text { ngkan } \\
\text { sebagai } \\
\text { aplikasi } \\
\text { yang } \\
\text { paling } \\
\text { penting, } \\
\text { percakapa } \\
\text { n, } \\
\text { sosialisasi } \\
\text { dan } \\
\text { pertukaran } \\
\text { dari tacit } \\
\text { knowledge } \\
\text { dipertimba } \\
\text { ngkan } \\
\text { untuk } \\
\text { menjadi } \\
\text { penggunaa } \\
\text { n utama } \\
\text { dari IT. }\end{array}$ & \\
\hline 6 & $\begin{array}{l}\text { Struktur } \\
\text { penghar } \\
\text { gaan } \\
\text { seperti } \\
\text { apa yang } \\
\text { ada } \\
\text { diperusa } \\
\text { haan } \\
\text { Anda? }\end{array}$ & $\begin{array}{l}\text { Karyawan } \\
\text { dihargai } \\
\text { atas } \\
\text { penggunaa } \\
\text { n dan } \\
\text { kontribusi } \\
\text { mereka } \\
\text { terhadap } \\
\text { database } \\
\text { seperti } \\
\text { database } \\
\text { diskusi } \\
\text { Notes. }\end{array}$ & 55 & $\begin{array}{l}\text { Karyawan } \\
\text { dihargai } \\
\text { atas } \\
\text { sharing } \\
\text { knowledge } \\
\text { yang } \\
\text { mereka } \\
\text { lakukan } \\
\text { secara } \\
\text { langsung } \\
\text { kepada } \\
\text { rekannya } \\
\text { dan ketika } \\
\text { membantu } \\
\text { masalah } \\
\text { rekannya } \\
\text { di lokasi/ } \\
\text { departeme } \\
\text { nt lain }\end{array}$ & 45 \\
\hline 7 & $\begin{array}{l}\text { Bagaima } \\
\text { na } \\
\text { pengeta } \\
\text { huan } \\
\text { dipertuk } \\
\text { arkan } \\
\text { dan } \\
\text { disampa } \\
\text { ikan? }\end{array}$ & $\begin{array}{l}\text { Pegawai } \\
\text { merujuk } \\
\text { kepada } \\
\text { dokumen } \\
\text { atau best } \\
\text { practices } \\
\text { database } \\
\text { yang } \\
\text { menyimpa } \\
\text { n, }\end{array}$ & 60 & $\begin{array}{l}\text { Pengetahu } \\
\text { an } \\
\text { ditransfer } \\
\text { orangpero } \\
\text { rang, } \\
\text { jejaring } \\
\text { dalam } \\
\text { perusahaa } \\
\text { n didorong } \\
\text { untuk }\end{array}$ & 40 \\
\hline
\end{tabular}

\begin{tabular}{|c|c|c|c|c|c|}
\hline $\begin{array}{l}\mathbf{N} \\
\mathbf{0}\end{array}$ & $\begin{array}{l}\text { Pertany } \\
\text { aan }\end{array}$ & Kodifikasi & $\begin{array}{c}\text { Bo } \\
\text { bot } \\
(\%) \\
)\end{array}$ & $\begin{array}{l}\text { Personali } \\
\text { sasi }\end{array}$ & $\begin{array}{c}\text { Bo } \\
\text { bot } \\
\text { (\% } \\
\text { ) }\end{array}$ \\
\hline & & $\begin{array}{l}\text { mendistrib } \\
\text { usikan dan } \\
\text { mengkolek } \\
\text { si } \\
\text { pengetahu } \\
\text { an } \\
\text { terkodifika } \\
\text { si. }\end{array}$ & & $\begin{array}{l}\text { memungki } \\
\text { nkan } \\
\text { sharing } \\
\text { tacit } \\
\text { knowledge } \\
\text { diamdiam, } \\
\text { dan } \\
\text { dengan } \\
\text { intuisi. }\end{array}$ & \\
\hline 8 & $\begin{array}{l}\text { Dimana } \\
\text { kah } \\
\text { posisi } \\
\text { skala ke } \\
\text { ekonomi } \\
\text { san } \\
\text { perusaha } \\
\text { an anda? }\end{array}$ & $\begin{array}{l}\text { Skala ke } \\
\text { ekonomisa } \\
\mathrm{n} \text { terletak } \\
\text { pada } \\
\text { keefektifa } \\
\mathrm{n} \text { dari } \\
\text { penggunaa } \\
\mathrm{n} \text { kembali } \\
\text { pengetahu } \\
\text { an dan } \\
\text { pengalama } \\
\mathrm{n} \text { yang } \\
\text { telah } \\
\text { ada/dimili } \\
\text { ki dan } \\
\text { penerapan } \\
\text { nya untuk } \\
\text { menyelesa } \\
\text { ikan } \\
\text { masalah- } \\
\text { masalah } \\
\text { baru dan } \\
\text { melengkap } \\
\text { i } \\
\text { proyekpro } \\
\text { yek baru. }\end{array}$ & 65 & \begin{tabular}{|l} 
Ke \\
ekonomisa \\
$\mathrm{n}$ berada \\
pada \\
jumlah \\
total \\
keahlian \\
yang \\
tersedia di \\
dalam \\
perusahaa \\
n, dimana \\
beberapa \\
ahli di \\
berbagai \\
area \\
tertentu \\
dianggap \\
diperlukan \\
.
\end{tabular} & 35 \\
\hline 9 & $\begin{array}{l}\text { Apa } \\
\text { kekhasa } \\
\mathrm{n} \\
\text { struktur } \\
\text { demogra } \\
\text { fik tim } \\
\text { anda? }\end{array}$ & $\begin{array}{l}\text { Tim besar; } \\
\text { sebagian } \\
\text { besar } \\
\text { anggota } \\
\text { adalah } \\
\text { pegawai } \\
\text { tingkat } \\
\text { junior; } \\
\text { beberapa } \\
\text { manajer } \\
\text { proyek } \\
\text { memimpin } \\
\text { mereka. }\end{array}$ & 60 & $\begin{array}{l}\text { Karyawan } \\
\text { junior } \\
\text { bukan } \\
\text { bagian } \\
\text { mayoritas } \\
\text { dari total } \\
\text { anggota } \\
\text { tim } \\
\text { umumnya. }\end{array}$ & 40 \\
\hline \multicolumn{3}{|c|}{ Total Bobot } & 510 & & 390 \\
\hline \multicolumn{3}{|c|}{ Rata-rata (\%) } & $\begin{array}{c}56, \\
6\end{array}$ & & $\begin{array}{c}43, \\
3\end{array}$ \\
\hline
\end{tabular}


Tabel 4 diatas menjelaskan bahwa strategi $K M$ dalam organisasi Pusat Komputer Universitas Tarumanagara lebih ke arah kodifikasi, dimana dokumentasi permasalahan-permasalahan terdahulu tersimpan dan digunakan kembali untuk menyelesaikan permasalahan baru. Disamping ada pula strategi personalisasi berupa kemampuan SDM yang menggambarkan ketersediaan tacit knowledge di dalam organisasi.

Perbandingan kodifikasi dan personalisasi diatas menunjukkan bahwa baik kodifikasi maupun personalisasi keduanya sama-sama digunakan dan dijalankan, ini berarti bahwa kedua strategi tersebut saling mendukung satu sama lain di dalam organisasi.

\subsection{Analisis Knowledge Management Usulan}

a. Diagram Alir Knowledge

Diagram alir knowledge menggambarkan aliran knowledge dari mana saja sumber pengetahuan berasal, kemana pengetahuan tersebut di simpan, lalu kemana pengetahuan tersebut di distribusikan. Adapun gambaran dari diagram alir knowledge dapat terlihat pada gambar 7 berikut

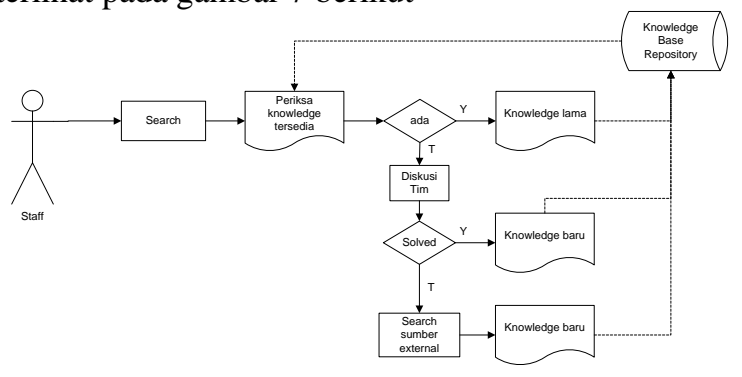

Gambar 7 Diagram Alir Knowledge

\section{b. Knowlegde Management Team}

Dalam penelitian ini di usulkan tim $K M$ yang akan bertanggung jawab terhadap kelangsungan $K M$ di Pusat Komputer Universitas Tarumanagara. Adapun usulan tersebut di ilustrasikan dalam bagan 8 berikut

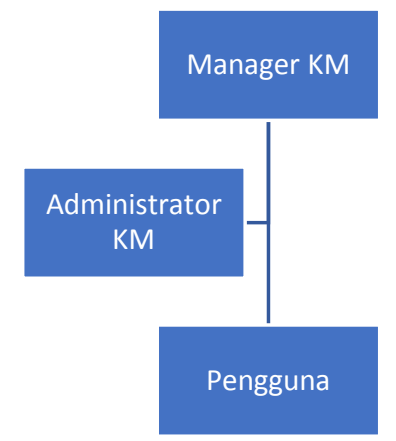

Gambar 8 Knowledge Management Team
Penjelasan fungsi dari masing-masing posisi tersebut sebagai berikut:

1) Manajer $K M$, sebagai penanggung jawab, serta mengorganisasikan berbagai inisiatif untuk kelangsungan pengembangan $K M$

2) Administrator $K M$, sebagai pengelola konten dari KM untuk dapat dikelola, disimpan, ditampilkan dan disebarluaskan. Serta mengatur hak akses pengguna $K M$.

3) Pengguna, sebagai pengguna yang memanfaatkan $K M$.

c. Knowledge Management Technology Usulan

Teknologi $K M$ yang dapat diterapkan untuk bagian pengembangan perangkat lunak di Pusat Komputer Universitas Tarumanagara, diuraikan dalam tabel 5 berikut

Tabel 5 Teknologi KM Usulan

\begin{tabular}{|c|c|c|c|c|}
\hline $\begin{array}{l}\text { Prose } \\
\text { s KM } \\
\end{array}$ & $\begin{array}{l}\text { Siste } \\
\text { m } K M\end{array}$ & $\begin{array}{l}K M \text { Sub } \\
\text { Proses }\end{array}$ & $\begin{array}{l}\text { Mekanis } \\
\text { me } K M\end{array}$ & $\begin{array}{l}\text { Teknol } \\
\text { ogi } K M\end{array}$ \\
\hline $\begin{array}{l}\text { Knowl } \\
\text { edge } \\
\text { Disco } \\
\text { very }\end{array}$ & $\begin{array}{l}\text { Knowl } \\
\text { edge } \\
\text { Disco } \\
\text { very } \\
\text { Sistem }\end{array}$ & $\begin{array}{l}\text { Combin } \\
\text { ation }\end{array}$ & $\begin{array}{l}\text { Dokume } \\
\mathrm{n} \\
\text { pengemb } \\
\text { angan, } \\
\text { dokume } \\
\mathrm{n} \\
\text { meeting, } \\
\text { laporan, } \\
\text { buku } \\
\text { referensi } \\
\text {, forum } \\
\text { diskusi } \\
\text { Percakap } \\
\text { an, } \\
\text { pelatihan } \\
\text { worksho } \\
\text { p, } \\
\text { pengama } \\
\text { tan, } \\
\text { project } \\
\text { collabor } \\
\text { ation }\end{array}$ & $\begin{array}{l}\text { Collabo } \\
\text { ration } \\
\text { system, } \\
\text { forum } \\
\text { diskusi, } \\
\text { chat, } \\
\text { email, } \\
\text { telepon }\end{array}$ \\
\hline $\begin{array}{l}\text { Knowl } \\
\text { edge } \\
\text { Captu } \\
\text { re }\end{array}$ & $\begin{array}{l}\text { Knowl } \\
\text { edge } \\
\text { Captu } \\
\text { re } \\
\text { Syste } \\
m\end{array}$ & $\begin{array}{l}\text { Internali } \\
\text { zation }\end{array}$ & $\begin{array}{l}\text { Training, } \\
\text { pengetah } \\
\text { uan dari } \\
\text { expert, } \\
\text { learning } \\
\text { by doing } \\
\text { Meeting, } \\
\text { face to } \\
\text { face, }\end{array}$ & $\begin{array}{l}\text { Reposit } \\
\text { ory, } \\
\text { forum } \\
\text { diskusi, } \\
\text { blog, } \\
\text { website } \\
\\
\text { Project } \\
\text { collabo } \\
\text { ration, } \\
\text { case }\end{array}$ \\
\hline
\end{tabular}




\begin{tabular}{|c|c|c|c|c|}
\hline & & & $\begin{array}{l}\text { collabor } \\
\text { ation }\end{array}$ & $\begin{array}{l}\text { base } \\
\text { reasoni } \\
n g\end{array}$ \\
\hline $\begin{array}{l}\text { Knowl } \\
\text { edge } \\
\text { Sharin } \\
\text { g }\end{array}$ & $\begin{array}{l}\text { Knowl } \\
\text { edge } \\
\text { Sharin } \\
\text { g } \\
\text { Syste } \\
m\end{array}$ & $\begin{array}{l}\text { Socializ } \\
\text { ation }\end{array}$ & $\begin{array}{l}\text { Face to } \\
\text { face, } \\
\text { meeting } \\
\\
\text { presenta } \\
\text { si }\end{array}$ & $\begin{array}{l}\text { Forum } \\
\text { diskusi, } \\
\text { blog, } \\
\text { chat, } \\
\text { knowled } \\
\text { ge } \\
\text { reposito } \\
\text { ry } \\
\text { Downlo } \\
\text { ad, } \\
\text { knowled } \\
\text { ge } \\
\text { search }\end{array}$ \\
\hline $\begin{array}{l}\text { Knowl } \\
\text { edge } \\
\text { Applic } \\
\text { ation }\end{array}$ & $\begin{array}{l}\text { Knowl } \\
\text { edge } \\
\text { Applic } \\
\text { ation } \\
\text { Syste } \\
m\end{array}$ & $\begin{array}{l}\text { Directio } \\
n\end{array}$ & $\begin{array}{l}\text { Kebijaka } \\
\mathrm{n}, \text { job } \\
\text { desc }\end{array}$ & $\begin{array}{l}\text { Pemeca } \\
\text { han } \\
\text { masalah } \\
\text { Sistem } \\
\text { informa } \\
\text { si } \\
\text { manaje } \\
\text { men }\end{array}$ \\
\hline
\end{tabular}

\subsection{Analisis Knowledge Management Blue Print}

a. Identifikasi Kebutuhan

Identifikasi kebutuhan terhadap rancangan knowledge management system berdasarkan hasil knowledge management usulan yang telah diuraikan diatas. Adapun hasil identifikasi kebutuhan tersebut di uraikan dalam tabel 6 berikut:

\begin{tabular}{|l|l|}
\multicolumn{1}{|c}{ Tabel 6 Identifikasi Kebutuhan } \\
\hline Kode & \multicolumn{1}{|c|}{ Deskripsi } \\
\hline R.001 & $\begin{array}{l}\text { Fitur pencarian pengetahuan atau case } \\
\text { tertentu }\end{array}$ \\
\hline R.002 & $\begin{array}{l}\text { Fitur penyimpanan dokumen-dokumen } \\
\text { serta file-file }\end{array}$ \\
\hline R.003 & $\begin{array}{l}\text { Fitur penyimpanan pengetahuan untuk } \\
\text { digunakan kembali dimasa mendatang } \\
\text { dalam sebuah knowledge repository }\end{array}$ \\
\hline R.004 & $\begin{array}{l}\text { Fitur penyimpanan experience dan } \\
\text { sharing experience, seperti blog, forum } \\
\text { atau chat }\end{array}$ \\
\hline R.005 & $\begin{array}{l}\text { Fitur collaboration untuk pengembangan } \\
\text { perangkat lunak }\end{array}$ \\
\hline R.007 & $\begin{array}{l}\text { Autentikasi login untuk menggunakan } \\
\text { sistem internal }\end{array}$ \\
\hline R.008 & $\begin{array}{l}\text { Tidak perlu login untuk menggunakan } \\
\text { sistem eksternal }\end{array}$ \\
\hline
\end{tabular}

b. Identifikasi Fitur

Infrastruktur fitur $K M$ dikategorikan sebagai teknologi informasi pendukung $K M$ yang didasarkan atas fungsi dan peran teknologi tersebut terhadap proses-proses $K M$ yang dalam hal ini menggunakan metode SECI (Socialization, Externalization, Combination dan Internalization). Identifikasi fitur ini juga mengacu pada identifikasi kebutuhan dari sistem yang telah dilakukan sebelumnya. Adapun fitur-fitur yang diidentifikasi berdasarkan konsep SECI, telah diuraikan dalam tabel 7 sebagai berikut

Tabel 7 Identifikasi Fitur
\begin{tabular}{|l|l|l|l|l|l|}
\hline No & Fitur & S & E & C & I \\
\hline 1 & Project collaboration & $\checkmark$ & & $\checkmark$ & \\
\hline 2 & Forum diskusi & $\checkmark$ & $\checkmark$ & & \\
\hline 3 & Web Blog / Portal KMS & & $\checkmark$ & & \\
\hline 4 & Knowledge Repository & & & $\checkmark$ & \\
\hline 5 & $\begin{array}{l}\text { Document } \\
\text { Management System }\end{array}$ & & & $\checkmark$ & \\
\hline 6 & Study Case & & & & $\checkmark$ \\
\hline
\end{tabular}

Kemudian dari hasil tabel diatas, maka dapat digambarkan secara lebih detail peran dari teknologi informasi berdasarkan konsep SECI, seperti digambarkan pada gambar 4.7 berikut

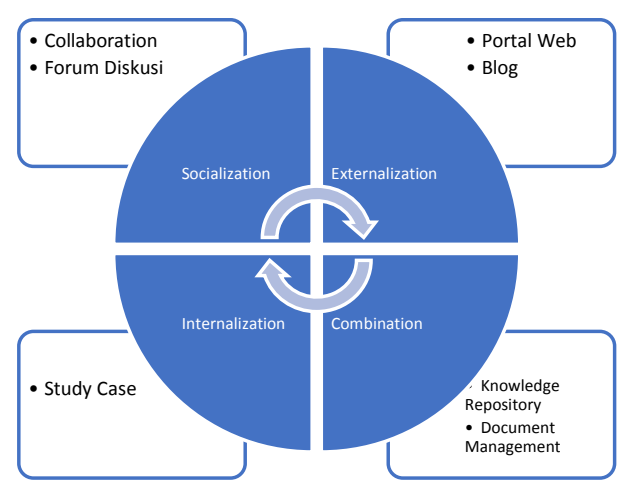

c. Knowledge Management Representation

Berdasarkan hasil identifikasi-identifikasi serta usulan yang telah dijelaskan sebelumnya, maka dibuat sebuah knowledge management representation sebagai gambaran knowledge management system beserta hubungan antara komponen sistem dan knowledge di dalamnya. Adapun gambaran knowledge representation tersebut dapat terlihat pada gambar 10 berikut 


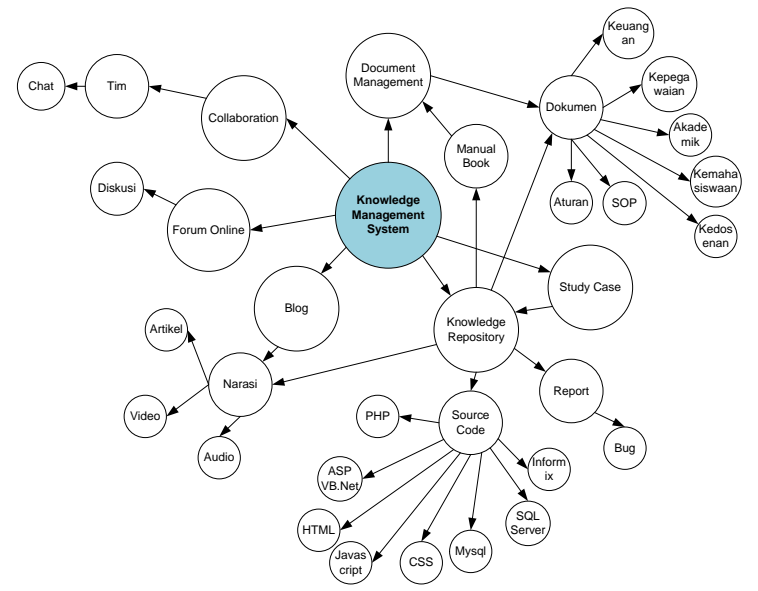

Gambar 10 Knowledge Management Representation

\subsection{Perancangan Sistem}

Pada tahap ini akan menjelaskan mengenai rancangan sistem berupa desain sistem yang meliputi diagram-diagram $u m l$ dan rancangan antar muka dari aplikasi knowledge management system.

\section{a. Use Case Diagram}

Berdasarkan hasil identifikasi kebutuhan sistem pada bagian analisis usulan diatas, dilakukan pemodelan sistem dengan use case diagram seperti ilustrasi gambar 11 berikut

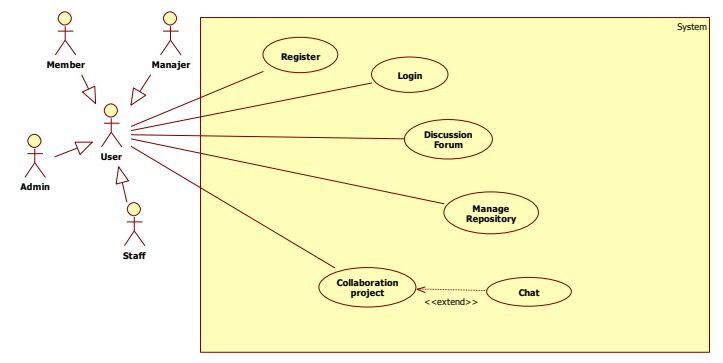

Gambar 11 Use Case Diagram KnowledgeManagement System

Dalam use case diagram diatas secara garis besar menampilkan beberapa use case utama yang menunjukkan interaksi user dengan sistem diantara Register, Login, Discussion Forum, Manage Repository, Collaboration, dan Chat.

\section{Gambar 9 Fitur KM dengan Konsep SECI}

\section{b. Class Diagram}

Adapun gambaran dari class diagram dari knowledge management system dalam penelitian ini akan di ilustrasikan dalam gambar 12 berikut

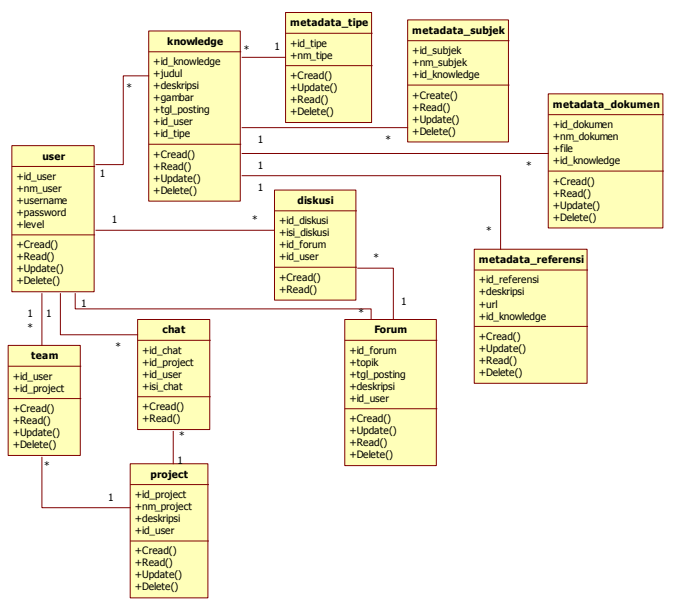

Gambar 12 Class Diagram Knowledge Management Sytem

c. Desain Arsitektur Sistem

Knowledge Management System dalam penelitian ini di rancang dan di implementasikan dalam model client-server, dimana data tersimpan di dalam sebuah database pada server internet dan diakses oleh banyak user. Adapun gambaran desain arsitektur sistem dapat terlihat pada gambar 13 berikut

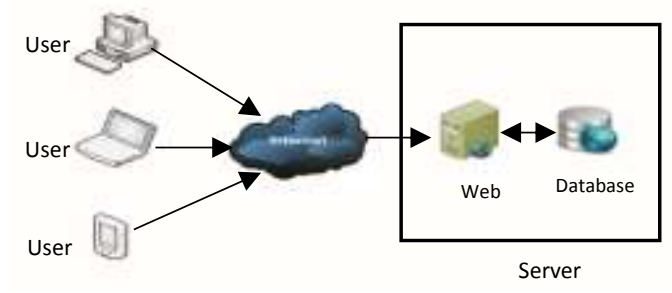

Gambar 13 Desain Arsitektur Sistem

\section{d. Desain Basis Data}

Basis data dalam knowledge management system pada penelitian ini digambarkan dalam domain model yang mengilustrasikan konsep hubungan antar entitas atau objek. Adapun ilustrasi tersebut dapat dilihat pada gambar 14 berikut

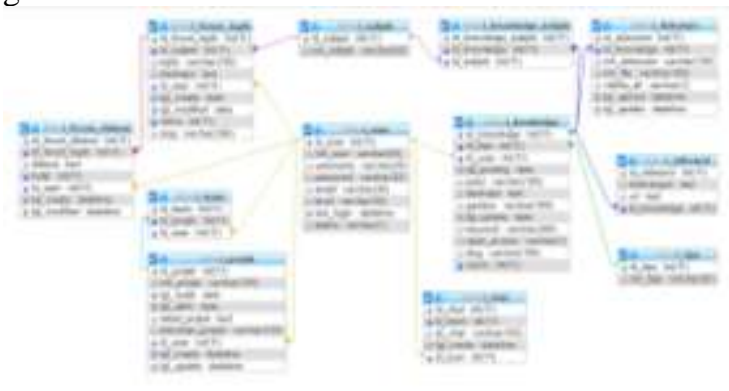

Gambar 14 Desain Basis Data 


\section{e. Hasil Rancangan Sistem}

Adapun hasil rancangan dari knowledge management system adalah sebagai berikut:

\section{1) Halaman Portal KMS}

Halaman ini merupakan halaman utama dari Portal Knowledge Management System, dimana dapat diakses oleh semua pengguna.
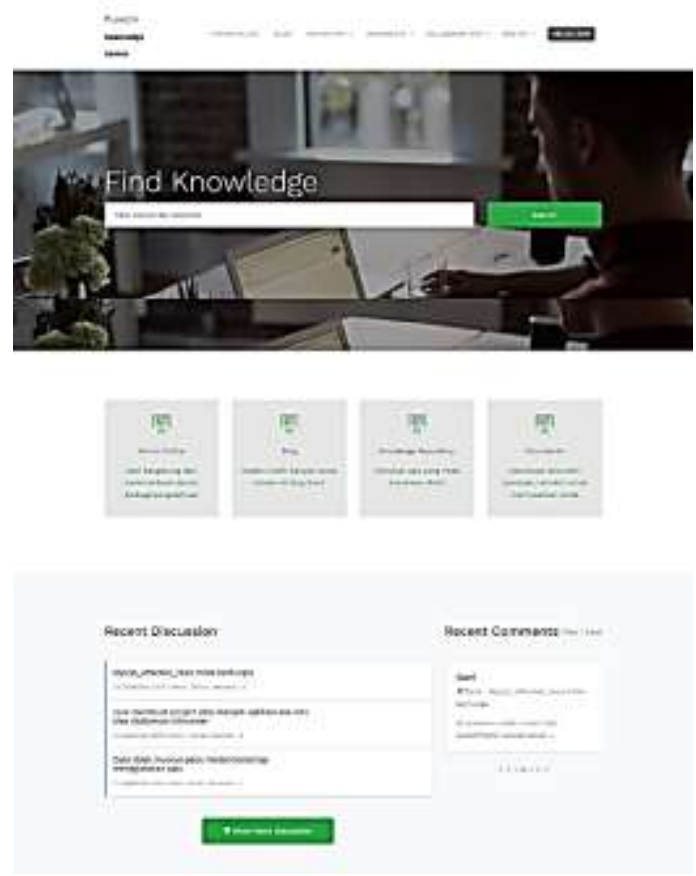

Gambar 15 Halaman Portal KMS

2) Halaman Forum Online

Halaman ini menampilkan diskusi-diskusi di dalam forum yang dapat di ikuti oleh pengguna yang telah memiliki autentikasi login user. Pengguna yang sudah teregistrasi dan login dapat berpartisipasi dalam diskusi online untuk saling berbagi pengetahuan atau mendiskusikan permasalahan-permasalahan.
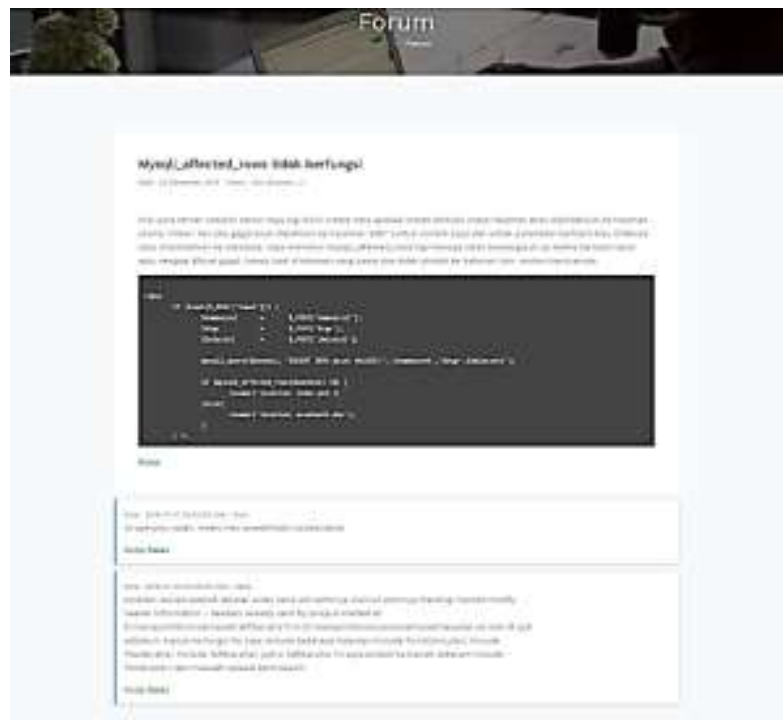

Gambar 16 Halaman Diskusi Forum

\section{3) Halaman Repository}

Halaman ini menampilkan kumpulan knowledge yang tersimpan di dalam database knowledge, baik berupa artikel, audio, video, dokumen, dan lain sebagainya. Knowledge-knowledge tersebut dapat diakses hanya oleh user internal sistem, yaitu staff, admin dan manager
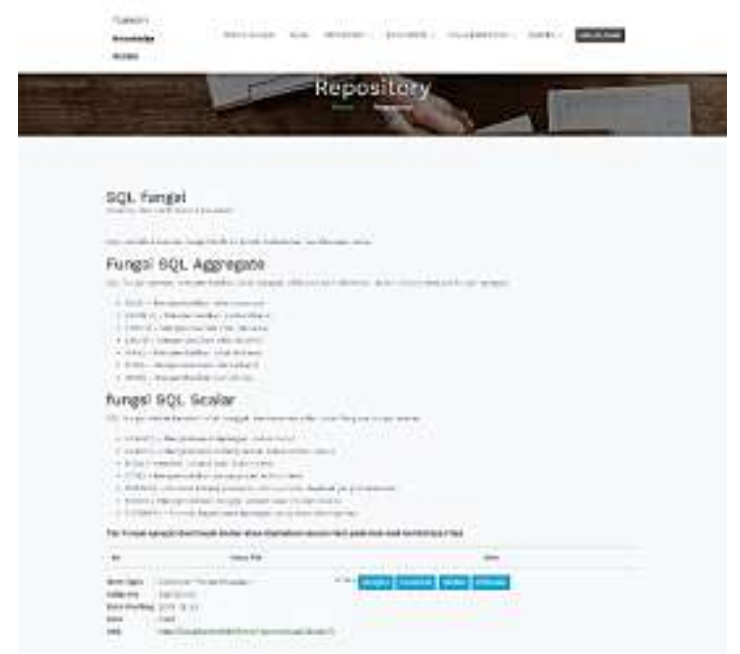

Gambar 17 Repository Detail

\section{f. Pengujian}

Pengujian rancangan sistem dalam penelitian ini menggunakan pengujian User Acceptance Test untuk menguji fungsionalitas dari fitur-fitur yang dikembangkan di dalam knowledge management system di Pusat Komputer Universitas Tarumanagara 


\section{User Acceptance Test (UAT)}

Dari hasil pengujian knowledge management system diperoleh hasil rata-rata sebesar $86,2 \%$. Hal ini dapat menunjukkan bahwa hasil knowlegde management system yang dirancang adalah baik. Knowledge management system secara fungsional maupun non-fungsional dapat diterima oleh pengguna dan menghasilkan rancangan yang sesuai kebutuhan pengguna.

\section{KESIMPULAN DAN SARAN}

Dari penelitian ini dapat ditarik kesimpulan bahwa pengetahuan merupakan hal yang sangat penting dan perlu dikelola dengan baik, untuk mendukung tersebarnya informasi dan pengetahuan untuk berbagai keperluan. Khususnya menyimpan berbagai pengalaman-pengalaman, permasalahanpermasalahan beserta solusinya dan digunakan kembali untuk menyelesaikan case serta membentuk pengetahuan baru.

Pada aspek rancangan, berhasil di identifikasi Fitur-fitur $K M$ yang berhasil berdasarkan kebutuhan pengguna yang mengacu pada konsep SECI yaitu Collaboration project, forum online, web portal KMS, Blog, Knowledge Repository, Document Management System, dan Study case.

Hasil pengujian knowledge management system diperoleh hasil rata-rata sebesar $86,2 \%$ yang berarti bahwa knowledge management system dapat berjalan dengan baik dan sesuai dengan kebutuhan pengguna.

Adapun saran yang dapat diberikan pernulis dalam penelitian ini diantaranya yaitu:

1. Kebijakan pimpinan Pusat Komputer Universitas Tarumanagara untuk mendorong kegiatan pengelolaan pengetahuan dan berbagi pengetahuan agar pengetahuan-pengetahuan di dalam knowledge management system dapat dimanfaatkan secara maksimal.

2. Di dalam penelitian ini penulis menggunakan pendekatan SECI model untuk menganalisis serta merancang berbagai fitur knowledge management system. Untuk itu pada penelitian selanjutnya penulis menyarankan untuk menggunakan pendekatan lain atau menggabungkan antara pendekatan satu dengan pendekatan lain untuk mendapatkan hasil yang lebih baik.

\section{DAFTAR PUSTAKA}

[1] D. B. Priambada, Implementasi Knowledge Management System di Perusahaan. Bogor: IPB, 2010.

[2] M. Bornemann, An Illustrated Guide to Knowledge Management. Graz, Austria: Wissenmanagement Forum, 2003.

[3] U. Chaeruman, "Analisis Model Konseptual Knowledge Management," Kaji. Lit. Karya Charles Despres Daniele Chauval, 2011.

[4] T. H. Davenport and L. Prusak, Working Knowledge: How Organizations Manage what They Know. Harvard Business Press, 1998.

[5] I. Becerra-Fernandez and R. Sabherwal, Knowledge Manamgement Systems and Processes. 2010.

[6] K. Dalkir, Knowledge Management in Theory and Practice. Burlington: Elsevier Butterworth-Heinemann USA, 2011.

[7] E. Cahyaningsih, D. I. Sensuse, A. M. Arymurthy, and W. C. Wibowo, "NUSANTARA: A New Model of Knowledge Management in Government Human Capital Management," Procedia Comput. Sci., vol. 124, pp. 61-68, 2017.

[8] A. Tiwana, The Knowledge Management Toolkit. New Jersey: Prentice Hall PTR, 1999.

[9] P. L. Tobing, "Knowledge Management: Manajemen Knowledge Sharing berbasis komunitas," Knowl. Manag. Soc. Indones., 2011.

[10] I. Nonaka and H. Takeuchi, The knowledge-creating company: how Japanese Companies create the dynmics of innovation. New York: Oxford University Press, 1995. 